Witold M. Orłowski*

\title{
Polska w strefie euro lub poza nią - scenariusze rozwoju
}

\begin{abstract}
Poland in or outside the eurozone - possible scenarios: This paper discusses the issue of Poland's future economic performance in the case of either adopting the euro or remaining outside the eurozone. The author claims that irrevocable fixing of the exchange rate deeply affects the economy. On the one hand, it allows for the microeconomic gains that, if fully exploited, may lead to faster growth and modernization. One the other hand, it brings about multiple risks, including challenges related to the adjustment to external shocks in the absence of monetary policy tools, as well as a risk of "the Southern eurozone countries' trap", namely excessive debt caused by easy access to inexpensive capital. Nevertheless, the key factor determining final outcome is the efficiency of functioning of the Polish economy, its economic policy, and institutions.
\end{abstract}

\footnotetext{
Słowa kluczowe: euro, polska gospodarka, polityka gospodarcza, rozwój gospodarczy Keywords: euro, Polish economy, economic policy, economic development

* Profesor doktor hab., Akademia Finansów i Biznesu Vistula • e-mail: witold.orlowski@vistula.edu.pl • https://orcid.org/oooo-0o02-2320-2372
}

\section{Wstęp}

Polska przystąpiła do Unii Europejskiej (UE) w roku 2004, akceptując warunki członkostwa w traktacie akcesyjnym (popartym przez społeczeństwo w referendum w roku 2003). Wśród warunków tych jest uczestnictwo w Unii Gospodarczej i Walutowej (UGW), a więc wprowadzenie euro. Wprowadzenie euro nie jest dla Polski kwestią wyboru - według ustaleń traktatowych euro jest docelowo wspólną walutą wszystkich krajów członkowskich UE (z wyjątkiem Wielkiej Brytania i Danii, które jako jedyne zagwarantowały sobie prawo podjęcia decyzji w tej sprawie) ${ }^{1}$. Kwestią wyboru jest jedynie moment wejścia

1 Zob. M. Götz, B.E. Nowak, W.M. Orłowski, Polska w strefie euro? Trzy scenariusze i ich prawdopodobne konsekwencje ogólnoekonomiczne, „Środkowoeuropejskie Studia Polityczne” 2019, nr 1, s. 124, https://doi.10.14746/ssp.2019.1.7. 
do strefy euro, zależny od zdolności kraju do trwałego wypełnienia warunków członkostwa w strefie. W momencie akcesji do UE Polska uzyskała status kraju członkowskiego objętego derogacją traktatową, co oznacza, że jest zobowiązana do zamiany złotego na euro dopiero wówczas, gdy wypełni tzw. kryteria konwergencji. W okresie obowiązywania derogacji jest jednak zobowiązana spełniać wymogi UGW, takie jak np. maksymalny dopuszczalny poziom deficytu budżetowego i długu publicznego.

Pomimo wykazanej wynikami gospodarczymi zdolności do przystąpienia do strefy euro (co dokumentuje faktyczne wypełnienie w latach 2016-2018 ekonomicznych kryteriów konwergencji, z wyjątkiem formalnego uczestnictwa w mechanizmie stabilizowania kursów walutowych ERM2) ${ }^{2}$, Polska od lat wstrzymuje się $\mathrm{z}$ decyzją $\mathrm{w}$ sprawie wprowadzenia wspólnej waluty. Z problemem tym wiąże się trwająca od lat zażarta dyskusja, w której padają argumenty na temat kosztów i korzyści członkostwa, zarówno w sferze gospodarczej, jak politycznej. Zdecydowanie niechętna szybkiemu wprowadzeniu euro w Polsce jest zarówno część partii politycznych, w tym rządzące Prawo i Sprawiedliwość, jak większość mieszkańców kraju. Polska oceniana jest więc powszechnie jako kraj, który mógłby wprowadzić euro, ale nie chce tego zrobić, sztucznie odwlekając ten moment w czasie głównie z powodów wewnątrzpolitycznych ${ }^{3}$.

Jednocześnie jednak pojawiają się opinie, że zmieniająca się architektura UE, a w szczególności rosnące prawdopodobieństwo silnych zmian instytucjonalnych i politycznych, przekształcających strefę euro w „twarde jądro” UE przy jednoczesnej marginalizacji stosunkowo nielicznych krajów pozostających poza strefą (zwłaszcza po brexicie), każą na nowo dokonać rachunku zysków i strat, a także zastanowić się nad ponownym przyspieszeniem procesu wprowadzenia w Polsce wspólnej waluty ${ }^{4}$. Jeśli założyć, że decyzja ta ma w głównej mierze wymiar polityczny i - być może - determinuje pozycję naszego kraju w UE, problemem staje się głównie to, w jaki sposób Polska powinna przygotować się do uczestnictwa w strefie euro, by zmaksymalizować płynące stąd korzyści i zminimalizować ryzyka.

W artykule przedstawione zostaną oceny możliwych scenariuszy gospodarczych uczestnictwa Polski w strefie euro lub pozostawania na zewnątrz tej strefy, a w szczególności długookresowych korzyści i ryzyka natury ekonomicznej związanych z tymi scenariuszami.

2 Zob. Europejski Bank Centralny, Raport o konwergencji, Frankfurt 2018, s. 66-67, https://doi.10.2866/29295.

${ }^{3}$ Zob. A. Dandashly, A. Verdun, Euro adoption in the Czech Republic, Hungary and Poland: Laggards by default and laggards by choice, „Comparative European Politics” 2018, Vol. 16(3), s. 405-407, https://doi.org/10.1057/cep.2015.46.

${ }^{4}$ Zob. M. Götz, B.E. Nowak, W.M. Orłowski, Polska w strefie euro?, op. cit., s. 124-125. 


\section{Scenariusze polityczne członkostwa Polski w strefie euro}

Scenariusze polityczne dotyczące relacji Polski ze strefą euro, wraz z możliwymi konsekwencjami prawnymi i gospodarczymi, przedstawione zostały w roku $2017 \mathrm{w}$ raporcie Co dalej z euro?5. W raporcie zostały sformułowane trzy scenariusze:

- „Scenariusz szybkiego wejścia”, oznaczający szybkie podjęcie decyzji politycznej na temat wejścia do strefy euro (do roku 2020), a następnie sprawne przeprowadzenie procesu akcesji, tak by było to możliwe do roku 2024-2025.

- „Scenariusz życia w przedpokoju”, oznaczający brak decyzji politycznej na temat wejścia do strefy euro. Polska korzysta nadal z derogacji, nie określając daty wprowadzenia euro (lub uzależniając ją od trudnych do spełnienia warunków).

- „Scenariusz trzaśnięcia drzwiami”, oznaczający podjęcie formalnej decyzji politycznej o niewprowadzaniu w Polsce euro, co oznacza złamanie zapisów i konieczność albo renegocjacji traktatu akcesyjnego, albo wyjścia z Unii Europejskiej.

Wspólnym założeniem wszystkich tych scenariuszy było to, że strefa euro do roku 2025 będzie znajdować się w pokryzysowej stabilizacji finansowej, dokona procesu usprawnienia i wzmocnienia mechanizmów swojego funkcjonowania, tworząc coraz bardziej zaawansowany, wielowymiarowy projekt integracyjny ${ }^{6}$. W takiej sytuacji kontynuacja polityki „życia w przedpokoju” staje się właściwie niemożliwa. Stosunkowo szybkie przystąpienie Polski do strefy euro („szybkie wejście") umożliwia pozostanie $\mathrm{w}$ centrum procesów integracyjnych, istotny wpływ na kształtowanie polityk UE, a w ślad za tym znaczne korzyści finansowe z budżetu UE oraz szansa na podwyższenie długookresowego tempa wzrostu polskiej gospodarki ${ }^{7}$. Formalna decyzja o niewprowadzaniu w Polsce euro („trzaśnięcie drzwiami”) może wręcz oznaczać początek procesu występowania Polski z UE, a z całą pewnością konieczność renegocjacji traktatu akcesyjnego, poważne osłabienie pozycji kraju, straty w zakresie wiarygodności finansowej,

${ }_{5}$ Zob. G. Gorzelak i in., Co dalej z euro? Trzy scenariusze dla Polski, Polska Fundacja im. Roberta Schumana, Warszawa 2017.

${ }^{6}$ Ibidem, s. 16-17. W sprawie przewidywanych kierunków reformy strefy euro do roku 2025 zob. T. Beck, Looking back at a lost decade; avoiding a second one [w:] Europe's Political Spring, Fixing the Eurozone and Beyond, eds. A. Bénassy-Quéré, F. Giavazzi, CEPR, London 2017.

7 Według szacunków NBP wprowadzenie euro oznaczałoby $0,2-0,7$ pkt proc. dodatkowego wzrostu PKB rocznie przez dekadę, zob. Narodowy Bank Polski, Raport na temat petnego uczestnictwa Rzeczypospolitej Polskiej w trzecim etapie Unii Gospodarczej i Walutowej, Warszawa 2009, s. 145. 
inwestycji i wzrostu gospodarczego, a także odczuwalną redukcję dochodów, które Polska czerpie z budżetu UE (być może nawet realny spadek o 55-60\% w stosunku do uzyskanych w perspektywie budżetowej 2014-2020) $)^{8}$.

Nie ulega oczywiście wątpliwości, że realizacja pesymistycznego dla Polski scenariusza zależy od wydarzeń wewnątrz UE, które nie muszą przebiegać zgodnie z przyjętymi założeniami dokończenia reform strefy euro i powstania na jej bazie „twardego jądra” UE. Raport należy jednak traktować jako prognozę ostrzegawczą, ukazującą możliwy, a według obecnego stanu wiedzy wysoce prawdopodobny, kierunek zmian w Unii.

\section{Argumenty ekonomiczne za wprowadzeniem euro i przeciwko wprowadzeniu}

Przed sformułowaniem i omówieniem scenariuszy ekonomicznych członkostwa Polski w strefie euro lub pozostawania poza nią niezbędne jest przypomnienie głównych argumentów ekonomicznych przemawiających za przystąpieniem i przeciwko niemu.

Wprowadzenie nieodwracalnie sztywnego kursu walutowego w stosunku do walut głównych partnerów gospodarczych, a w szczególności udział w unii walutowej i członkostwo kraju w strefie euro, wiąże się z powszechnie znaną, długą listą korzyści oraz ryzyk. W syntetycznej formie, nieuwzględniającej oczywiście całej złożoności problemu i interakcji między zmiennymi makro- i mikroekonomicznymi, przedstawia je tabela 1 .

Tabela 1. Główne korzyści i koszty związane z uczestnictwem we wspólnym obszarze walutowym

\begin{tabular}{|c|c|}
\hline Korzyści & Koszty \\
\hline $\begin{array}{l}\text { Bezpośrednie: } \\
\text { - } \text { redukcja ryzyka kursowego } \\
\text { - } \text { redukcja kosztów transakcyjnych } \\
\text { stóp procentowych } \\
\text { - } \text { korzyści z posiadania pieniądza międzynarodowego } \\
\text { - mniejsze zapotrzebowanie na rezerwy walutowe } \\
\text { Pośrednie: } \\
\text { - ożywienie wymiany handlowej } \\
\text { - } \text { większa integracja rynków finansowych } \\
\text { - wzrost inwestycji (w tym bezpośrednich inwesty- } \\
\text { - } \text { cji zagranicznych) } \\
\text { - wzrosza przejrzystość i porównywalność cen } \\
\text { wzonkurencji }\end{array}$ & $\begin{array}{l}\text { - } \text { rezygnacja z własnej polityki pieniężnej (utrata } \\
\text { autonomiczności ustalania wysokości stóp pro- } \\
\text { centowych) } \\
\text { - } \text { rezygnacja z własnej polityki kursowej (utrata } \\
\text { możliwości wpływania na kurs walutowy, w tym } \\
\text { konkurencyjnej dewaluacji) } \\
\text { - nieuzasadniony wzrost cen w momencie wprowa- } \\
\text { dzania euro } \\
\text { - koszty techniczne i organizacyjne } \\
\text { - utrata części dochodów sektora finansowego } \\
\text { - koszty wynikające z asymetrycznych szoków } \\
\text { makroekonomicznych (np. wzrost bezrobocia, } \\
\text { nierównowaga w bilansie płatniczym) } \\
\text { - udział w kosztach pomocy dla zadłużonych kra- } \\
\text { jów strefy euro (funduszu stabilizacyjnym strefy } \\
\text { euro) }\end{array}$ \\
\hline
\end{tabular}

Źródło: W.M. Orłowski, Dlaczego Polska powinna przyjać euro? [w:] Ekonomia i polityka. Wokół teorii Grzegorza W. Kołodko, red. E. Mączyńska, PWN, Warszawa 2019, s. 433.

\footnotetext{
${ }^{8}$ Zob. G. Gorzelak i in., Co dalej z euro?, op. cit., s. 37-40.
} 
W toczonej w Polsce dyskusji ekonomicznej zdecydowanie przeważa teza, że efektem występowania bezpośrednich i pośrednich korzyści z wprowadzenia euro jest przyspieszenie długookresowego tempa wzrostu PKB, a korzyści przeważają nad ewentualnymi kosztami, mającymi po części charakter jednorazowych kosztów dostosowawczych? . Wśród głównych korzyści wymienia się zazwyczaj: (1) wzrost wiarygodności i stabilności, a w ślad za tym zachętę do oszczędzania i inwestowania; (2) spadek ceny kapitału; (3) ograniczenie kosztów związanych z wymianą walut; (4) uniknięcie ryzyka niestabilności kursu walutowego stanowiącego pożywkę dla spekulacji; (5) wzrost atrakcyjności Polski jako miejsca lokalizowania inwestycji mimo rosnących płac, zwiększenie stopnia integracji z innymi gospodarkami, a przez to łatwiejsze osiąganie przez polskie przedsiębiorstwa korzyści skali i łatwiejszy transfer wiedzy. Nie oznacza to jednak lekceważenia ryzyk - najważniejszymi problemami w przypadku Polski wydają się być: (1) ograniczenie krótkookresowych zdolności dostosowawczych gospodarki w efekcie rezygnacji z autonomicznej polityki pieniężnej i kursowej; (2) negatywne efekty związane z niewłaściwym kursem wymiany złotego na euro (zbyt wysoki kurs oznaczałby niską wycenę polskiego majątku, zbyt niski kurs prowadziłby do czasowej utraty konkurencyjności eksportu); (3) ryzyko „pułapki krajów południa strefy euro”, czyli nadmiernego wzrostu zadłużenia i utraty konkurencyjności gospodarczej; (4) uniknięcie znaczącego wzrostu cen związanego z wprowadzeniem euro ${ }^{10}$.

Przed sformułowaniem scenariuszy omówione zostaną w syntetyczny sposób te kwestie, które należy uznać za kluczowe dla efektów wprowadzenia przez Polskę euro lub trwałego pozostawania poza strefą wspólnej waluty. Pominięte będą jednak problemy mające krótkookresowy charakter dostosowawczy (takie jak np. właściwe ukształtowanie kursu wymiany czy ewentualny wzrost cen po wprowadzeniu euro - możliwości jego ograniczenia, wynikające m.in. $z$ analizy doświadczeń innych krajów, omówione są w innych publikacjach $\left.{ }^{11}\right)$. W artykule skoncentrowano się więc jedynie na trzech kluczowych problemach: (1) realizacji korzyści w zakresie długookresowego wzrostu gospodarczego przy stałym kursie walutowym; (2) zdolności dostosowawczych gospodarki niedysponującej możliwością dostosowania polityki pieniężnej i kursowej; (3) ryzyka „pułapki krajów południa strefy euro".

9 Zob. Narodowy Bank Polski, Raport na temat pelnego uczestnictwa, op. cit.; G. Gorzelak i in., Co dalej z euro?, op. cit.; W.M. Orłowski, W pogoni za straconym czasem. Wzrost gospodarczy w Europie Środkowo-Wschodniej 1950-2030, PWE, Warszawa 2010, s. 213-219.

${ }_{10}$ G. Gorzelak i in., Co dalej z euro?, op. cit.

11 Zob. M. Götz i in., Jak żyć z euro? Doświadczenia krajów Europy Środkowo-Wschodniej, Polska Fundacja im. Roberta Schumana, Warszawa 2018. 


\section{Długookresowy wzrost gospodarczy przy stałym i zmiennym kursie walutowym}

Czy w warunkach sztywnego kursu walutowego rzeczywiście możliwe jest trwałe przyspieszenie rozwoju gospodarczego i wykorzystanie niewątpliwych korzyści mikroekonomicznych, tworzonych przez większą stabilność i wiarygodność finansową kraju? Doświadczenia światowe nie dają jednoznacznej odpowiedzi w sprawie wyższości strategii kursu płynnego nad stałym (i odwrotnie) w promowaniu wzrostu gospodarczego. Część badań sugeruje lepsze efekty kursu płynnego i kontroli inflacji ${ }^{12}$, inne pokazują przewagę kursu stałego ${ }^{13}$. Formułowana jest też teza, że wybór strategii kursowej ma zdecydowanie większe znaczenie dla krajów rozwijających się, o słabym systemie finansowym, niż dla krajów rozwiniętych ${ }^{14}$. Wśród krytyków strategii kursu stałego panuje przekonanie, że w dłuższym okresie brak narzędzi dostosowawczych do szoków (polityki pieniężnej i kursowej) odgrywa rolę kluczową, prowadząc raczej do strat w zakresie PKB niż korzyści ${ }^{15}$.

Należy jednak zwrócić uwagę, że w warunkach sztywnego kursu walutowego dostosowanie do ewentualnego szoku również jest możliwe. Musi jednak odbywać się za pomocą innych narzędzi niż w przypadku kursu płynnego: zamiast dewaluacji i osłabienia waluty niezbędne jest wówczas w krótkim okresie zmniejszenie kosztów produkcji (ograniczenie płac lub zatrudnienia), a w dłuższym okresie sięgnięcie po narzędzia przyspieszonego wzrostu wydajności pracy (co promuje długookresowy wzrost ${ }^{16}$ ). Doświadczenia historyczne pokazują, że w warunkach dobrze funkcjonującej gospodarki narzędzia takie są wystarczające do radzenia sobie $\mathrm{z}$ wahaniami gospodarczymi.

Jako przykład warto porównać doświadczenia czterech krajów europejskich, stosujących różne strategie polityki kursów swojej waluty w stosunku do głównego partnera gospodarczego - Niemiec (do czasu zjednoczenia w roku 1990 tylko zachodniej części kraju): Wielkiej Brytanii, Szwecji, Austrii i Holandii.

12 Zob. K.-M.Wong, T. Tai-Leung Chong, Monetary policy regimes and growth revisited: evidence from a de facto classification, „Oxford Economic Papers” 2019, Vol. 71, No 4, s. 1-22, https://doi.10.1093/oep/gpy068.

${ }_{13}$ Zob. M. Ashour, C.C. Yong, The impact of exchange rate regimes on economic growth: Empirical study of a set of developing countries during the period 1974-2006, „The Journal of International Trade \& Economic Development" 2017, Vol. 27, s. 74-90, https://doi.org/10.1 080/09638199.2017.1339117.

${ }^{14}$ Zob. J. Frankel, X. Ma, D. Xie, The Impact of Exchange Rate Regimes on Economic Growth with Continuous Classification of de facto Regimes, „Harvard Web Publishing” 2019, https://scholar.harvard.edu/files/frankel/files/fmaxie_errgr_2019apr26.pdf.

15 Najbardziej rozwiniętą i udokumentowaną krytykę polityki stałego kursu walutowego, sformułowaną w Polsce, zawiera praca: S. Kawalec, E. Pytlarczyk, Paradoks euro. Jak wyjść z pułapki wspólnej waluty?, Poltext, Warszawa 2016.

16 Zob. OECD, The Sources of Economic Growth in OECD Countries, OECD, Paris 2003, s. 99-102. 
Wykres 1 pokazuje długookresową politykę prowadzoną przez te kraje w drugiej połowie XX wieku. Jak widać, w przypadku Wielkiej Brytanii i Szwecji mieliśmy do czynienia z płynnym kształtowaniem się kursu walutowego, pozwalającym na absorpcję szoków i utrzymanie konkurencyjności poprzez osłabienie waluty w przypadku występowania znacznych różnic inflacyjnych wobec Niemiec. Z kolei Austria i Holandia stosowały strategię opartą na stabilnej relacji kursów walut do marki niemieckiej (aż do momentu wprowadzenia w roku 1999 euro), skutecznie dostosowując do tego celu swoją politykę pieniężną (co oznaczało, że kraje te faktycznie nie stosowały jej jako narzędzia dostosowawczego $)^{17}$.

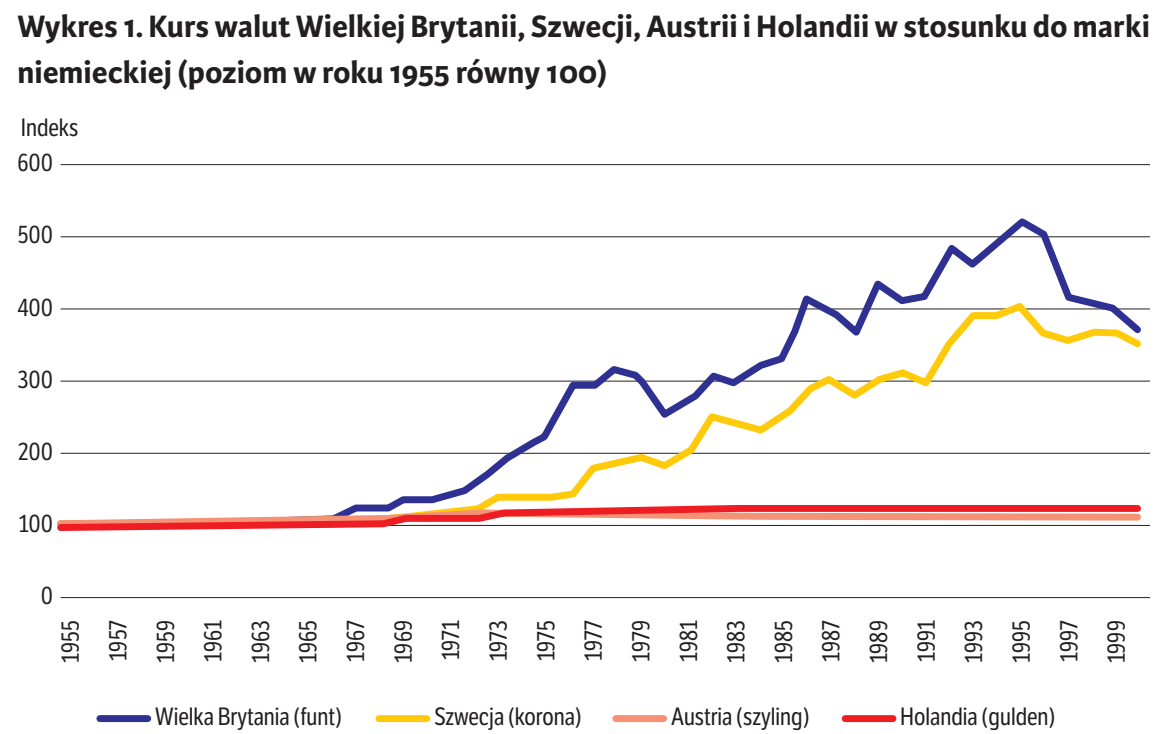

Źródło: Międzynarodowy Fundusz Walutowy.

Dane przedstawione w tabeli 2 pokazują długookresowe wyniki prowadzonej polityki gospodarczej w czterech porównywanych krajach, na tle Niemiec, w zakresie stabilności waluty i wzrostu PKB.

W ciągu badanych 45 lat w Austrii i Holandii doszło jedynie do niewielkiego nominalnego osłabienia walut w stosunku do marki niemieckiej (najsilniejszego w momencie silnej rewaluacji marki wobec dolara w roku 1969, stanowiącej koniec długotrwałej ery rozwoju RFN opierającej się na niedowartościowanej walucie $\left.^{18}\right)$. W tym samym czasie bardziej miękka, aktywna w przeciwdziałaniu

17 Bardziej szczegółową analizę rozwoju gospodarczego badanych krajów zawiera analiza OECD, ibidem, s. 57-70.

18 Zob. M. Dahl, Niemiecki model społecznej gospodarki rynkowej jako wzór dla polskich przemian systemowych po 1989 roku, Elipsa, Warszawa 2015, s. 88-89. 
Tabela 2. Długookresowy wzrost gospodarczy przy różnej polityce kursowej, 19552000

\begin{tabular}{|c|c|c|c|c|c|}
\hline & Niom & $\begin{array}{r}\text { Kraje o pł } \\
\text { wob }\end{array}$ & $\begin{array}{l}\text { ym kursie } \\
\text { DEM }\end{array}$ & $\begin{array}{r}\text { Kraje o sta } \\
\text { wob }\end{array}$ & $\begin{array}{l}\text { nym kursie } \\
\text { DEM }\end{array}$ \\
\hline & & $\begin{array}{l}\text { Wielka } \\
\text { Brytania }\end{array}$ & Szwecja & Austria & Holandia \\
\hline Kurs waluty wobec DEM & & & & & \\
\hline 1955 & 1,00 & 0,08 GBP & 1,23 SEK & 6,19 ATS & $0,91 \mathrm{NLG}$ \\
\hline 2000 & 1,00 & $0,31 \mathrm{GBP}$ & 4,33 SEK & 7,04 ATS & $1,13 \mathrm{NLG}$ \\
\hline Zmiana nominalnego kursu w \% & $x$ & $268 \%$ & $252 \%$ & $14 \%$ & $24 \%$ \\
\hline Indeks cen (poziom 1955 równy 1) & & & & & \\
\hline 1955 & 1,0 & 1,0 & 1,0 & 1,0 & 1,0 \\
\hline 2000 & 3,8 & 14,4 & 11,6 & 5,2 & 5,6 \\
\hline Skumulowana inflacja w \% & $377 \%$ & $1443 \%$ & $1158 \%$ & $516 \%$ & $561 \%$ \\
\hline $\begin{array}{l}\text { Skumulowane różnice inflacyjne } \\
\text { wobec Niemiec w \% }\end{array}$ & $x$ & $283 \%$ & $207 \%$ & $37 \%$ & $49 \%$ \\
\hline PKB per capita $($ Niemcy $=100)$ & & & & & \\
\hline 1955 & 100 & 123 & 116 & 75 & 107 \\
\hline 2000 & 100 & 101 & 107 & 105 & 118 \\
\hline $\begin{array}{l}\text { Zmiana PKB per capita w stosunku } \\
\text { do Niemiec w \% }\end{array}$ & $x$ & $-18 \%$ & $-7 \%$ & $41 \%$ & $10 \%$ \\
\hline
\end{tabular}

DEM - marka niemiecka; GDB - funt angielski; SEK - korona szwedzka; ATS - szyling austriacki; NLG gulden hlenderski.

Źródło: Międzynarodowy Fundusz Walutowy, Maddison Project.

szokom polityka pieniężna Wielkiej Brytanii i Szwecji doprowadziła do dwuipółkrotnego nominalnego osłabienia funta i korony wobec marki. Takie zmiany siły waluty były niezbędne $\mathrm{w}$ celu zachowania konkurencyjności w warunkach znacznie silniejszego wzrostu cen niż w Niemczech, wynikającego z dwukrotnie wyższej średniej inflacji - ok. 6\% średniorocznie, wobec 3\% w Niemczech (dzięki stabilnemu kursowi walut, inflacja w Austrii i Holandii wynosiła średniorocznie odpowiednio 3,7 i 3,9\%, a więc niewiele więcej niż w Niemczech).

Mimo stosowania stałego kursu walutowego i rezygnacji z narzędzi polityki pieniężnej w celu pobudzania gospodarki i absorpcji szoków, wzrost PKB Austrii i Holandii okazał się w okresie 1955-2000 szybszy niż w Niemczech, co wiodło do poprawy relacji PKB per capita wobec Niemiec. Z kolei w stosujących aktywną politykę pieniężną Wielkiej Brytanii i Szwecji tempo wzrostu PKB było niższe niż w Niemczech, co prowadziło do znacznego pogorszenia tej relacji. Szczególnie wyraźny jest tu sukces rozwojowy Austrii, która stosując konsekwentnie politykę stałego kursu walutowego przekształciła się z kraju znacznie uboższego od Niemiec w kraj o wyraźnie wyższym poziomie dochodów od znacznie większego sąsiada ${ }^{19}$.

19 Więcej szczegółów zawiera opracownanie: M. Hołda, Dlaczego Austria (niemal) dogoniła Szwajcarię? [w:] Zagadki wzrostu gospodarczego, red. L. Balcerowicz, A. Rzońca, CH Beck, Warszawa 2000, s. 114-150. 
Jak więc widać, w przypadku odpowiedniej sprawności działania gospodarki, możliwe jest długookresowe zachowanie wysokiej dynamiki rozwoju i radzenie sobie z szokami bez użycia narzędzi polityki pieniężnej.

Związki pomiędzy długookresowym wzrostem PKB a stabilnością (lub niestabilnością) kursu walutowego w 17 państwach Europy Zachodniej (kraje "starej UE” oraz Szwajcaria, Norwegia i Islandia) dokumentuje wykres 2. Uwagę zwraca przede wszystkim brak jednoznacznej zależności: wyraźną poprawę relacji PKB per capita w stosunku do Niemiec odnotowały zarówno kraje stosujące politykę stabilnego kursu (Austria, kraje Beneluxu), jak aktywnie stosujące politykę pieniężną (kraje południa strefy euro). Podobnie rzecz wygląda z pogorszeniem relacji, zarówno w krajach o stabilnym kursie (Szwajcaria), jak o kursie silnie zmiennym (Islandia). Ciekawy jest przypadek Irlandii. W latach 1955-1985 stosowała ona aktywną politykę pieniężną, prowadzącą do znacznego osłabienia waluty wobec marki, przy braku poprawy relacji PKB per capita w stosunku do Niemiec. W latach 1986-2000, po całkowitej zmianie strategii rozwoju gospodarczego ${ }^{20}$, polityce stabilnej waluty towarzyszyła ogromna redukcja różnic dochodowych w stosunku do Niemiec (w roku 2000 Irlandia przegoniła Niemcy pod względem PKB per capita).

Wykres 2. Wzrost PKB per capita i stabilność waluty w 17 państwach Europy Zachodniej, 1955-2000 (w \%)

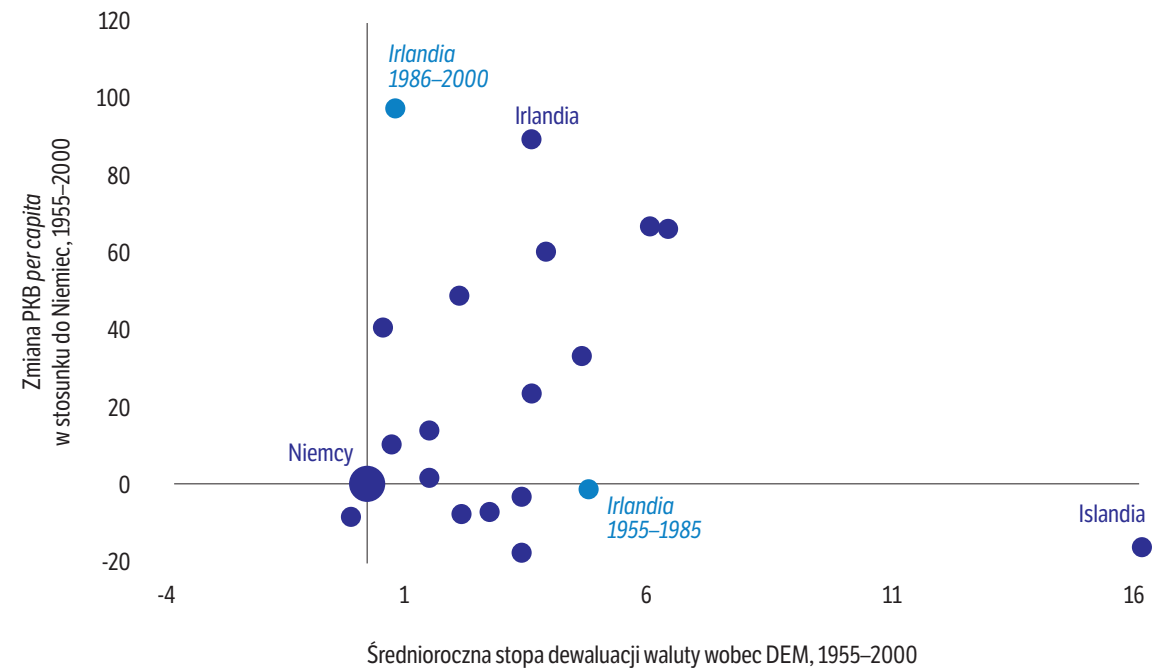

Źródło: jak pod tabelą 2.

20 Zob. OECD, The Sources of Economic Growth, op. cit., s. 49-51. 
Jak się więc wydaje, w pełni uzasadniony jest wniosek, że „deterministyczne” podejście sugerujące, że bez aktywnego stosowania narzędzi polityki pieniężnej i elastyczności polityki kursowej nie jest możliwe długookresowe utrzymanie konkurencyjności i skuteczna absorpcja szoków, sformułowane m.in. przez S. Kawalca i E. Pytlarczyka ${ }^{21}$, należy uznać za nieuzasadnione. Istotą problemu nie jest bowiem sama strategia polityki makroekonomicznej, ale zapewnienie sprawnego działania mechanizmów dostosowawczych spójnych z tą polityką.

\section{Dostosowanie do szoków przy stałym i zmiennym kursie walutowym}

Rezygnacja $\mathrm{z}$ autonomicznej polityki pieniężnej jest oczywistą konsekwencją nieodwracalnego usztywnienia kursu walutowego, a w ostatecznym rachunku wprowadzenia euro. Pozbawia to kraj potężnego narzędzia łagodzenia szoków gospodarczych i ograniczania amplitudy wahań koniunkturalnych, zmuszając do sięgania po narzędzia dostosowań realnych (głównie wzrost wydajności) i po wewnętrzną dewaluację (głównie ograniczenie płac) jako reakcję na kłopoty gospodarcze oraz pogorszenie konkurencyjności ${ }^{22}$.

Ważnym elementem odpowiedzi na pytanie, $w$ jakim stopniu ryzyko to wpływa na rozwój gospodarczy, jest sięgnięcie do doświadczeń krajów o zbliżonej strukturze gospodarki i podobnych doświadczeniach w zakresie transformacji gospodarczej do Polski. Oczywistym punktem odniesienia jest w tym przypadku Słowacja, która wprowadziła euro w roku $2009^{23}$. Różnica skali gospodarek każe jednak analizować wyniki gospodarcze Słowacji w odniesieniu nie do Polski, ale Czech - kraju również o zbliżonej strukturze gospodarki, lecz w podobnym stopniu (wyższym niż w Polsce) uzależnionego od handlu zagranicznego, który jednak pozostał przy własnej, umiejętnie zarządzanej walucie.

Najbardziej interesujące jest porównanie, w jaki sposób oba kraje poradziły sobie najpierw z silnym szokiem finansowym, wywołanym przez globalny kryzys finansowy (po upadku banku Lehman Brothers we wrześniu 2008 r.), a następnie z recesją w krajach strefy euro (głównych partnerach handlowych obu krajów) w roku 2009 i w latach 2012-2013. Dane na ten temat zawarte są w tabeli 3.

Gwałtowna recesja w strefie euro w roku 2009 (spadek PKB rzędu -4,5\%) spowodowała czasowe załamanie czeskiego i słowackiego eksportu do strefy. Ścieżki dostosowania się obu krajów do szoku przebiegały jednak inaczej.

${ }^{21}$ S. Kawalec, E. Pytlarczyk, Paradoks euro, op. cit.; zob. M. Obstfeld, J.D. Ostry, M.S. Qureshi, Global Financial Cycles and the Exchange Rate Regime: A Perspective from Emerging Markets, „AEA Papers and Proceedings” 2018, Vol. 108, s. 499-504.

${ }^{22}$ Zob. A. Belke, C. Dreger, Current Account Imbalances in the Euro Area: Catching Up or Competitiveness?, Deutsches Institut für Wirtschaftsforschung, DIW Discussion Papers nr 1106, Berlin 2011, s. 3-4.

${ }^{23}$ Zob. M. Götz i in., Jak żyć z euro?, op. cit., s. 18-25. 
W przypadku Czech nastąpiło wyraźne nominalne osłabienie waluty (o 5,7\%), podczas gdy w używającej od roku 2009 euro Słowacji nie było już takiej możliwości. Ponowne osłabienie czeskiej korony o 12\% nastąpiło podczas kolejnej recesji w strefie euro (w latach 2012-2014).

Efektem braku możliwości dostosowania nominalnego stały się różne efekty dostosowania realnego. Podczas gdy w Czechach osłabiła się siła nabywcza wyrażona w euro, a także wzrosła czasowo inflacja (łącznie w latach 2009-2010 wyniosła 3,5\%), na Słowacji siła nabywcza pozostała niemal niezmieniona, a inflacja wyniosła w latach 2009-2010 jedynie 1,3\%. Jednocześnie Słowacja zaznała znacznie bardziej gwałtownego dostosowania realnego, skutkującego spadkiem PKB w roku 2009 o 5,4\% (w Czechach o 4,8\%) i wzrostem stopy bezrobocia o 4,9 pkt proc. w latach 2009-2010 (w Czechach o 2,9 pkt proc.).

Tabela 3. Dostosowanie Czech i Słowacji do szoku zewnętrznego, 2008-2015

\begin{tabular}{|c|c|c|c|c|c|c|c|c|}
\hline & 2008 & 2009 & 2010 & 2011 & 2012 & 2013 & 2014 & 2015 \\
\hline \multicolumn{9}{|c|}{ Tempo wzrostu PKB w \% } \\
\hline Czechy & 2,7 & $-4,8$ & 2,3 & 1,8 & $-0,8$ & $-0,5$ & 2,7 & 5,3 \\
\hline Słowacja & 5,6 & $-5,4$ & 5,0 & 2,8 & 1,7 & 1,5 & 2,8 & 3,9 \\
\hline \multicolumn{9}{|c|}{ Dewaluacja waluty wobec euro w \% } \\
\hline Czechy & $-10,0$ & 5,7 & $-4,1$ & $-3,2$ & 1,9 & 3,9 & 6,1 & $-1,1$ \\
\hline Słowacja & $-7,4$ & 0,0 & 0,0 & 0,0 & 0,0 & 0,0 & 0,0 & 0,0 \\
\hline \multicolumn{9}{|c|}{ Stopa bezrobocia w \% } \\
\hline Czechy & 4,4 & 6,7 & 7,3 & 6,7 & 7,0 & 7,0 & 6,1 & 5,0 \\
\hline Słowacja & 9,6 & 12,1 & 14,5 & 13,7 & 14,0 & 14,2 & 13,2 & 11,5 \\
\hline
\end{tabular}

Uwaga: lata recesji w strefie euro oznaczono szarym tłem.

Źródło: Międzynarodowy Fundusz Walutowy.

Nie ulega wątpliwości, że płynny kurs walutowy pomógł Czechom nieco lepiej poradzić sobie $\mathrm{z}$ efektami gwałtownego szoku zewnętrznego $\mathrm{w}$ roku 2009. Z drugiej jednak strony, już w roku 2010 Słowacja odzyskała zdolność do szybkiego wzrostu, znacznie lepiej od Czech reagując na kolejny gwałtowny szok $\mathrm{z}$ lat 2012-2013 (zachowanie dodatniego tempa wzrostu PKB, przy nieco większym niż w Czechach wzroście bezrobocia). Jak pokazuje powyższy przykład, choć przystąpienie do strefy euro na krótką metę rzeczywiście utrudnia dostosowanie do szoków zewnętrznych, w dłuższym okresie efekt ten nie musi już mieć znaczenia. Argument o korzyści z utrzymania własnej waluty nie jest więc bezzasadny, ale nie należy go traktować jako rozstrzygającego w analizie kosztów i korzyści członkostwa w strefie euro.

\section{Ryzyko „pułapki krajów południa strefy euro”}

Kolejnym niezwykle ważnym ryzykiem związanym z członkostwem Polski w strefie euro jest ryzyko powtórzenia się niekorzystnych zjawisk gospodarczych 
Tabela 4. Zmiany zadłużenia krajów południa strefy euro w latach 2000-2013 (w \%)

\begin{tabular}{|c|c|c|c|c|c|}
\hline & \multicolumn{3}{|c|}{ Dług w relacji do PKB } & \multicolumn{2}{|c|}{$\begin{array}{l}\text { Zmiana poziomu długu } \\
\text { w relacji do PKB }\end{array}$} \\
\hline & 2000 & 2007 & 2013 & $2000-2007$ & 2007-2013 \\
\hline \multicolumn{6}{|l|}{ Hiszpania } \\
\hline Gospodarstwa domowe & 45 & 81 & 77 & 36 & -4 \\
\hline Firmy & 73 & 124 & 120 & 51 & -4 \\
\hline Sektor prywatny & & & & & \\
\hline Razem & 118 & 205 & 197 & 87 & -8 \\
\hline Sektor rządowy & 61 & 37 & 100 & -24 & 63 \\
\hline Dług razem & 179 & 242 & 297 & 63 & 55 \\
\hline \multicolumn{6}{|l|}{ Portugalia } \\
\hline Gospodarstwa domowe & 59 & 87 & 86 & 28 & -1 \\
\hline Firmy & 82 & 110 & 135 & 28 & 25 \\
\hline Sektor prywatny & & & & & \\
\hline Razem & 141 & 197 & 221 & 56 & 24 \\
\hline Sektor rządowy & 56 & 73 & 131 & 17 & 58 \\
\hline Dług razem & 197 & 270 & 352 & 73 & 82 \\
\hline \multicolumn{6}{|l|}{ Włochy } \\
\hline Gospodarstwa domowe & 23 & 38 & 43 & 15 & 5 \\
\hline Firmy & 56 & 75 & 81 & 19 & 6 \\
\hline Sektor prywatny & & & & & \\
\hline Razem & 79 & 113 & 124 & 34 & 11 \\
\hline Sektor rządowy & 113 & 105 & 139 & -8 & 34 \\
\hline Dług razem & 192 & 218 & 263 & 26 & 45 \\
\hline \multicolumn{6}{|l|}{ Grecja } \\
\hline Gospodarstwa domowe & 14 & 51 & 65 & 37 & 14 \\
\hline Firmy & 40 & 55 & 64 & 15 & 9 \\
\hline Sektor prywatny & & & & & \\
\hline Razem & 54 & 106 & 129 & 52 & 23 \\
\hline Sektor rządowy & 107 & 106 & 170 & -1 & 64 \\
\hline Dług razem & 161 & 212 & 299 & 51 & 87 \\
\hline
\end{tabular}

Źródło: McKinsey Global Institute.

i finansowych, które miały miejsce w krajach południa strefy euro, a najbardziej gwałtowny przebieg miały w Grecji.

Przyjmując euro, kraje południa strefy euro zyskały dostęp do taniego kapitału, co powinno było przełożyć się na większe inwestycje (finansowane tanim kredytem) i szybszy wzrost PKB. Błędna polityka gospodarcza i regulacyjna w sektorze finansowym oraz wysoki poziom korupcji i niesprawność instytucji publicznych spowodowały jednak, że kredyt został wykorzystany głównie na sfinansowanie nadmiernego wzrostu konsumpcji, wydatków rządu albo na inwestycje nieefektywne, nieprzekładające się na wzrost $\mathrm{PKB}^{24}$. W konsekwencji wzrostowi zadłużenia nie towarzyszył wzrost konkurencyjności gospodarki,

${ }^{24}$ Zob. A. Belke, C. Dreger, Current Account Imbalances, op. cit., s. 2-6. 


\section{Wykres 3. Saldo obrotów bieżących krajów południa strefy euro i Niemiec w latach 2000-2013}

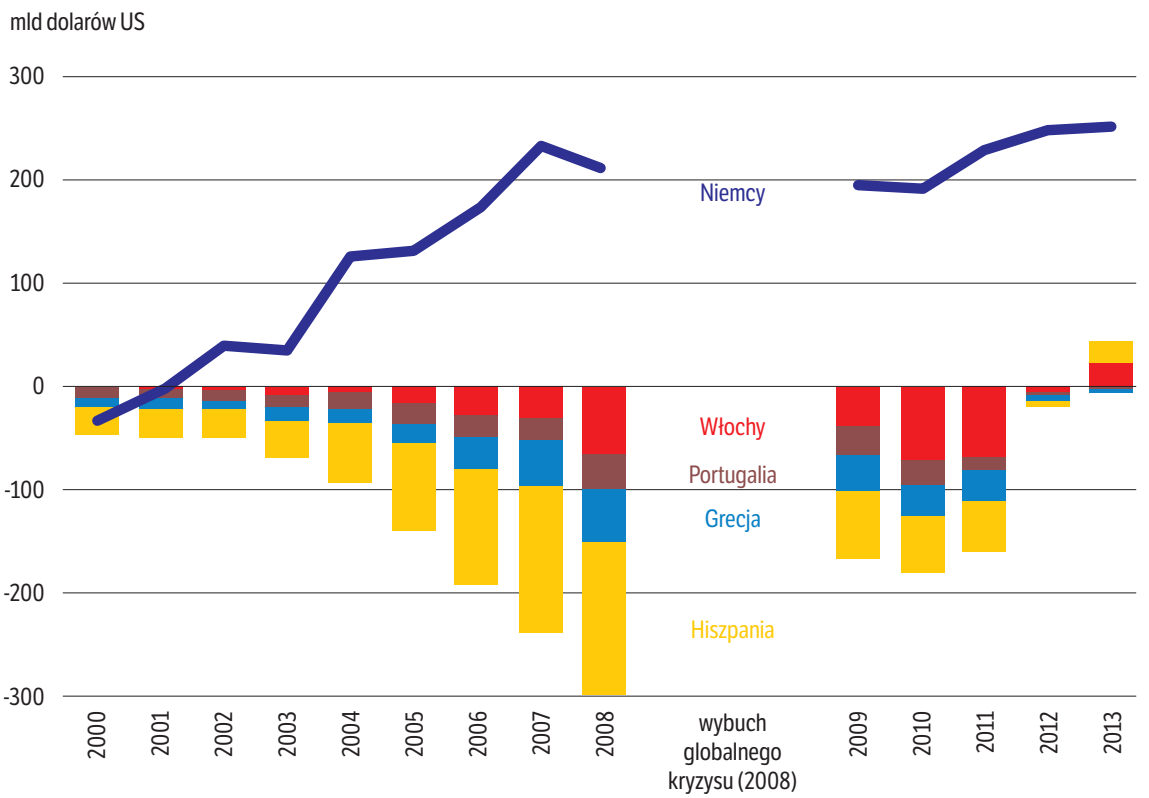

Źródło: Międzynarodowy Fundusz Walutowy.

ale zjawiska odwrotne, prowadzące w stronę pułapki zadłużenia. W skrajnym przypadku Grecji doprowadziło to do groźby bankructwa, której zażegnanie wymagało uruchomienia procesu wsparcia przez pozostałe kraje strefy i częściowej redukcji zadłużenia. Dane na temat wzrostu zadłużenia krajów południa strefy euro, w podziale na sektory instytucjonalne, przedstawione są w tabeli 4 .

Jak widać, mechanizmy zadłużania się krajów południa strefy euro nie były jednakowe. W latach 2000-2007 w Hiszpanii mieliśmy do czynienia z ogromnym wzrostem zadłużenia przedsiębiorstw, zwłaszcza z sektora deweloperskiego. Towarzyszył temu boom gospodarczy zachęcający do wzrostu zadłużenia gospodarstwa domowe, jednocześnie prowadzący do pozornej poprawy stanu finansów publicznych (spadku zadłużenia sektora rządowego). Podobnie wyglądała sytuacja we Włoszech, natomiast w Portugalii i Grecji zadłużenie sektora rządowego wzrastało wraz z zadłużeniem sektora prywatnego, mimo dobrej koniunktury gospodarczej. Wybuch kryzysu spowodował, że w latach 2008-2013 wzrost zadłużenia sektora prywatnego uległ we wszystkich czterech krajach przyhamowaniu, natomiast nastąpił silny i zagrażający stabilności finansowej wzrost długu publicznego, wynikający w znacznej mierze z przejęcia przez państwo konsekwencji kryzysu finansowego. 
Należy przy tym zauważyć, że proces nadmiernego wzrostu zadłużenia sektora prywatnego w latach 2000-2007 był możliwy dzięki wadliwemu funkcjonowaniu mechanizmów strefy euro, umożliwiających niekontrolowany przepływ kapitału z krajów o nadwyżkach (głównie z Niemiec), do nadmiernie zadłużających się krajów południa strefy euro (zob. wykres 3 ). Wprowadzone w minionych latach reformy funkcjonowania strefy euro, jak pakiet rozporządzeń i dyrektyw (Pakt fiskalny, tzw. sześciopak, dwupak), nadzór makro- i mikroostrożnościowy, budowa unii bankowej - znacznie ograniczają ryzyko powtórzenia się takiej sytuacji ${ }^{25}$.

Przy wszystkich zastrzeżeniach co do mechanizmów funkcjonowania strefy euro, nie ulega jednak wątpliwości, że źródło kryzysu krajów południa strefy euro tkwiło w ich własnej polityce gospodarczej i niesprawności instytucjonalnej, prowadzących prosto do pułapki zadłużeniowej (najpierw w sektorze prywatnym, potem w publicznym). Wśród czynników o największym znaczeniu znajdowała się słabość regulacyjna w sektorze finansowym, brak odpowiedniej reakcji polityki fiskalnej na narastające problemy, a także niska elastyczność rynku pracy. W efekcie zjawiskom zadłużania się najpierw towarzyszyło gwałtowne pogorszenie się konkurencyjności (wzrost deficytów obrotów bieżących do poziomu 9,6\% PKB w Hiszpanii, 12,1\% w Portugalii i 15,2\% w Grecji; niebezpiecznego wzrostu deficytu nie odnotowały jedynie Włochy). Następnie, już po wybuchu kryzysu, szok zewnętrzny, recesja i konieczność ograniczenia nierównowagi w bilansie płatniczym doprowadziły do wzrostu bezrobocia do $12 \%$ we Włoszech, 16\% w Portugalii, 26\% w Hiszpanii i 28\% w Grecji.

\section{Scenariusze rozwoju Polski w strefie euro lub poza nią}

Powyższe rozważania jasno pokazują, że w trakcie analiz rozwoju Polski w strefie euro lub poza nią (oczywiście przy założeniu, że niewprowadzanie euro nie spowoduje opuszczenia przez Polskę UE, a jedynie pogorszenie warunków członkostwa $\left.{ }^{26}\right)$, nie da się sformułować jednoznacznie scenariuszy rozwoju, bez dokonania odpowiednich założeń co do sprawności i skuteczności polityki gospodarczej Polski oraz jakości instytucji. Czynniki te decydują o tym, na ile kraj jest w stanie wykorzystać szanse tworzone przez stabilny pieniądz w sferze mikroekonomicznej w celu przyspieszenia wzrostu PKB i zintensyfikowania zmian strukturalnych, na ile sprawnie jest w stanie dostosowywać się do szoków i na ile skutecznie może zminimalizować ryzyka, które występują czy to przy posługiwaniu się euro, czy walutą krajową.

Należy przy tym zauważyć, że poza problemem dynamiki rozwoju (wzrostu PKB) ważny z punktu widzenia Polski jest też wpływ decyzji dotyczących

25 Zob. T. Beck, Looking back at a lost decade, op. cit., s. 23-25.

${ }^{26}$ Zob. M. Götz, B.E. Nowak, W.M. Orłowski, Polska w strefie euro?, op. cit., s. 126. 
wprowadzenia euro na zmiany modelu gospodarczego, a w szczególności na uniknięcie tzw. pułapki średniego rozwoju ${ }^{27}$, i przejście od modelu rozwoju opartego na relatywnie niskich kosztach pracy do modelu opartego na wiedzy i innowacjach, dominującego w rozwiniętych gospodarkach rynkowych ${ }^{28}$.

W uproszczonej analizie rozwoju Polski w ciągu najbliższych 10-20 lat skonstruować więc można cztery podstawowe scenariusze, schematycznie przedstawione w tabeli 5. W zależności od przyjętych założeń, możemy mieć: (1) wprowadzenie euro przy sprawnej polityce i instytucjach krajowych; (2) pozostawanie poza strefą euro przy sprawnej polityce i instytucjach krajowych; (3) wprowadzenie euro przy niesprawnej polityce i instytucjach krajowych; (4) pozostawanie poza strefą euro przy niesprawnej polityce i instytucjach krajowych. Prawdopodobne efekty takich scenariuszy przedstawione są w tabeli 6.

Tabela 5. Schemat konstrukcji scenariuszy rozwoju Polski

\begin{tabular}{|c|c|c|c|}
\hline & \multicolumn{2}{|c|}{ Decyzja w sprawie wprowadzenia euro } \\
\hline & & Wejście do strefy euro & Pozostawanie poza strefą euro \\
\hline \multirow{2}{*}{$\begin{array}{l}\text { Jakość } \\
\text { polityki } \\
\text { i instytucji } \\
\text { Polski }\end{array}$} & $\begin{array}{l}\text { Skuteczna polityka, } \\
\text { sprawna gospodarka } \\
\text { i instytucje }\end{array}$ & $\begin{array}{l}\text { Scenariusz rozwoju i szybkiej } \\
\text { modernizacji }\end{array}$ & $\begin{array}{l}\text { Scenariusz rozwoju } \\
\text { i spowolnionej modernizacji }\end{array}$ \\
\hline & $\begin{array}{l}\text { Nieskuteczna polityka, } \\
\text { sprawna gospodarka } \\
\text { i instytucje }\end{array}$ & $\begin{array}{l}\text { Scenariusz powolnego rozwoju } \\
\text { i ryzyka }\end{array}$ & Scenariusz regresu i ryzyka \\
\hline
\end{tabular}

Wyniki przedstawionych scenariuszy można syntetycznie scharakteryzować w sposób zaprezentowany poniżej.

- W przypadku scenariusza rozwoju i szybkiej modernizacji (wejście do strefy euro przy sprawnych instytucjach i skutecznej polityce gospodarczej Polski) możliwy jest szybki rozwój i modernizacja, prowadząca w stronę pożądanych zmian modelu rozwoju Polski.

- W przypadku scenariusza rozwoju i spowolnionej modernizacji (pozostawanie poza strefą euro przy sprawnych instytucjach i skutecznej polityce gospodarczej Polski) możliwy jest również stosunkowo szybki rozwój, jednak silne ograniczenie środków na inwestycje i modernizację (wynikające zarówno z osłabienia pozycji w UE, jak i z utrzymania się większego ryzyka inwestycyjnego) prowadzi do spowolnienia zmian modelu rozwoju i ryzyka pułapki średniego rozwoju.

- W przypadku scenariusza powolnego rozwoju i ryzyka (wejście do strefy euro przy niesprawnych instytucjach i skutecznej polityce gospodarczej Polski) rozwój byłby spowolniony, a zmiany modelu wyhamowane (co wynikałoby z niskiej efektywności wykorzystania dostępnych środków),

27 Zob. P. Agénor, O. Canuto, M. Jelenic, Avoiding Middle-Income Growth Traps, „Economic Premise" 2012, nr 98.

${ }_{28}$ Zob. OECD, The Sources of Economic Growth, op. cit., s. 51-54. 
Tabela 6. Scenariusze rozwoju Polski

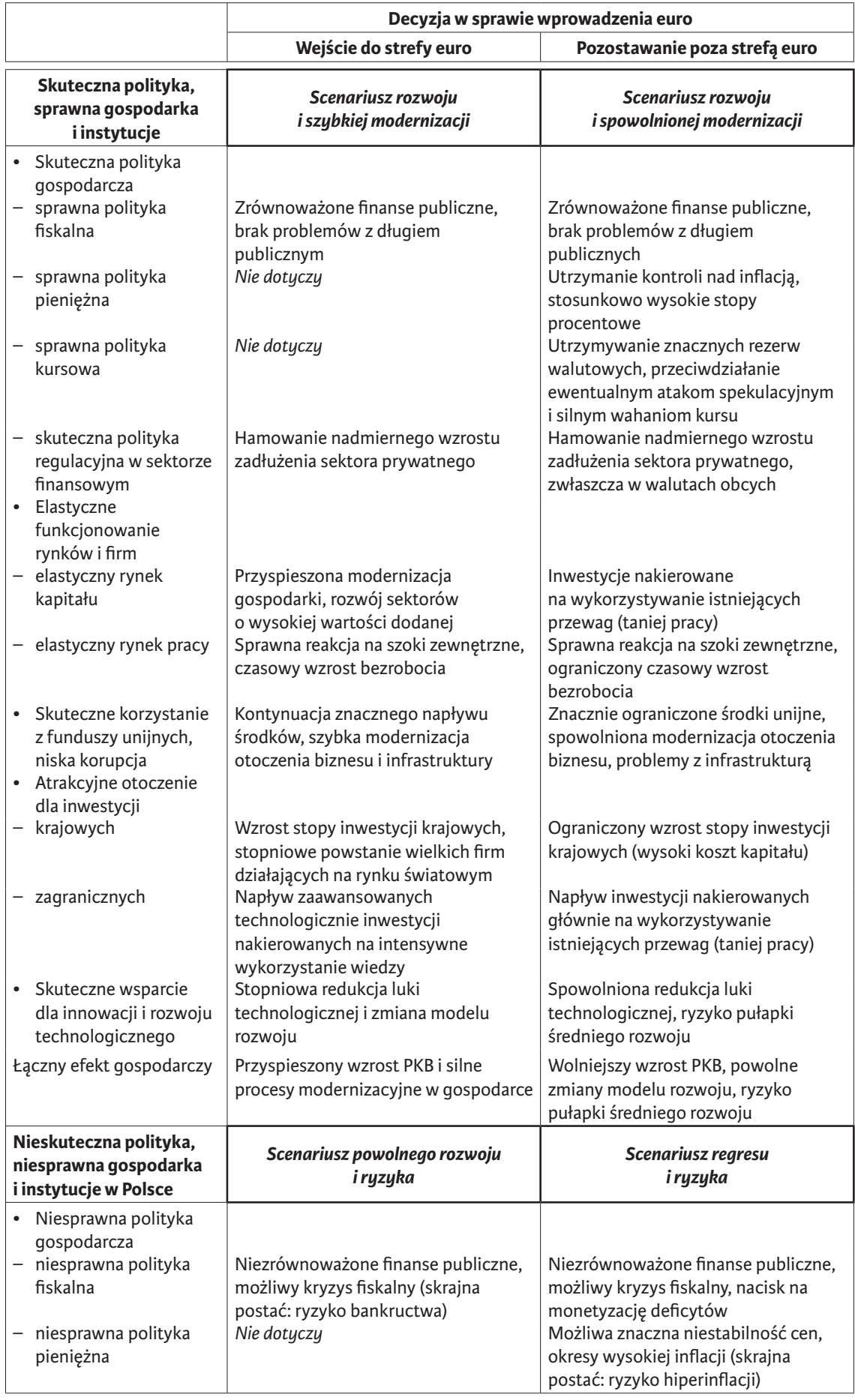




\begin{tabular}{|c|c|c|}
\hline & \multicolumn{2}{|c|}{ Decyzja w sprawie wprowadzenia euro } \\
\hline & Wejście do strefy euro & Pozostawanie poza strefą euro \\
\hline $\begin{array}{l}\text { - } \text { sprawna polityka } \\
\text { kursowa } \\
\text { - } \text { nieskuteczna polityka } \\
\text { regulacyjna w sektorze } \\
\text { finansowym } \\
\text { - Nieelastyczne } \\
\text { funkcjonowanie } \\
\text { rynków i firm }\end{array}$ & $\begin{array}{l}\text { Nie dotyczy } \\
\text { Silny wzrost zadłużenia, możliwy } \\
\text { kryzys bankowy }\end{array}$ & $\begin{array}{l}\text { Silne wahania kursu, możliwe ataki } \\
\text { spekulacyjne i kryzys walutowy } \\
\text { Silny wzrost zadłużenia w walutach } \\
\text { obcych, możliwy kryzys bankowy }\end{array}$ \\
\hline $\begin{array}{l}\text { - nieelastyczny rynek } \\
\text { kapitału }\end{array}$ & $\begin{array}{l}\text { Spadek efektywności inwestycji, } \\
\text { inwestycje w sektorach } \\
\text { niskoproduktywnych }\end{array}$ & $\begin{array}{l}\text { Spadek efektywności inwestycji, } \\
\text { problemy ze spłatą kredytów } \\
\text { (zwłaszcza w walutach obcych) }\end{array}$ \\
\hline $\begin{array}{l}\text { - nieelastyczny rynek } \\
\text { pracy }\end{array}$ & $\begin{array}{l}\text { Silny wzrost bezrobocia w reakcji } \\
\text { na szoki zewnętrzne lub kryzys } \\
\text { wewnętrzny }\end{array}$ & $\begin{array}{l}\text { Silny wzrost bezrobocia w reakcji } \\
\text { na szoki zewnętrzne lub kryzys } \\
\text { wewnętrzny }\end{array}$ \\
\hline $\begin{array}{l}\text { - Nieskuteczne } \\
\text { korzystanie z funduszy } \\
\text { unijnych, niska }\end{array}$ & $\begin{array}{l}\text { Kontynuacja znacznego napływu } \\
\text { środków, marnotrawstwo środków } \\
\text { silnie ograniczone efekty }\end{array}$ & $\begin{array}{l}\text { Znacznie ograniczone środki unijne, } \\
\text { zahamowana modernizacja otoczenia } \\
\text { biznesu, marnotrawstwo }\end{array}$ \\
\hline $\begin{array}{l}\text { - Nieatrakcyjne } \\
\text { otoczenie dla inwestycji }\end{array}$ & & \\
\hline - krajowych & $\begin{array}{l}\text { Silnie ograniczona stopa inwestycji } \\
\text { krajowych }\end{array}$ & $\begin{array}{l}\text { Silnie ograniczona stopa inwestycji } \\
\text { krajowych }\end{array}$ \\
\hline - zagranicznych & $\begin{array}{l}\text { Ograniczony napływ inwestycji, } \\
\text { nakierowanych głównie na rynek } \\
\text { krajowy }\end{array}$ & $\begin{array}{l}\text { Silnie ograniczony napływ inwestycji } \\
\text { zagranicznych }\end{array}$ \\
\hline $\begin{array}{l}\text { Nieskuteczne wsparcie } \\
\text { dla innowacji i rozwoju } \\
\text { technologicznego }\end{array}$ & $\begin{array}{l}\text { Utrzymanie się luki technologicznej } \\
\text { i modelu rozwoju }\end{array}$ & Wzrost luki technologicznej \\
\hline Łączny efekt gospodarczy & $\begin{array}{l}\text { Powolny wzrost PKB, pułapka } \\
\text { średniego rozwoju, ryzyko pułapki } \\
\text { krajów południa strefy euro }\end{array}$ & $\begin{array}{l}\text { Wyhamowanie wzrostu PKB, regres } \\
\text { w zakresie modernizacji }\end{array}$ \\
\hline
\end{tabular}

co prowadziłoby do pułapki średniego rozwoju, a w skrajnej sytuacji do wejścia w pułapkę krajów południa strefy euro.

- Najgorsze wyniki dałby jednak scenariusz regresu i ryzyka (pozostawanie poza strefą euro przy niesprawnych instytucjach i nieskutecznej polityce gospodarczej Polski), oznaczający w warunkach ograniczonych środków wyhamowanie wzrostu PKB i regres w zakresie modernizacji.

\section{Podsumowanie}

Decyzja na temat wejścia Polski do strefy euro lub pozostania poza strefą ma ogromne znaczenie dla rozwoju, jednak jej efekty w ogromnym stopniu zależą od skuteczności prowadzonej przez kraj polityki gospodarczej, sprawności gospodarki oraz jakości instytucji. Sprawnie działająca gospodarka jest w stanie dobrze rozwijać się zarówno w strefie euro, jak poza nią, choć większa dostępność środków w scenariuszu zakładającym wprowadzenie euro (wyższe inwestycje i większe środki z budżetu UE), przy jednoczesnym nacisku na wzrost efektywności, potencjalnie pozwalają na osiągnięcie szybszego wzrostu 
i przyspieszenie procesów modernizacji (oczywiście przy skutecznej polityce przemysłowej, realizowanej według współczesnych, prorynkowych zasad ${ }^{29}$ ). Przy pozostawaniu Polski poza strefą euro zwiększa się ryzyko wpadnięcia kraju w pułapkę średniego rozwoju.

Znacznie gorsze perspektywy rozwoju dają scenariusze, w których polska gospodarka działa w sposób niesprawny. W przypadku wprowadzenia euro prowadziłoby to do powolnego rozwoju, pozostawania w pułapce średniego rozwoju, a w skrajnym przypadku do kryzysu zadłużeniowego wywołanego wpadnięciem w pułapkę krajów południa strefy euro. Przy pozostawaniu poza strefą euro, wobec silnie ograniczonych środków prowadziłoby to do wyhamowania wzrostu PKB i regresu w zakresie modernizacji, a także do ryzyka ciężkich kryzysów (fiskalnego, bankowego, walutowego, inflacyjnego).

\section{Bibliografia}

Agénor P., Canuto O., Jelenic M., Avoiding Middle-Income Growth Traps, „Economic Premise" 2012, No 98.

Ashour M., Yong C.C., The impact of exchange rate regimes on economic growth: Empirical study of a set of developing countries during the period 1974-2006, „The Journal of International Trade \& Economic Development” 2017, Vol. 27, https://doi.org/10.1 080/09638199.2017.1339117.

Beck T., Looking back at a lost decade; avoiding a second one [w:] Europe's Political Spring, Fixing the Eurozone and Beyond, red. A. Bénassy-Quéré, F. Giavazzi, CEPR, London 2017.

Belke A., Dreger C., Current Account Imbalances in the Euro Area: Catching Up or Competitiveness?, DIW Discussion Papers nr 1106, Deutsches Institut für Wirtschaftsforschung, Berlin 2011.

Dahl M., Niemiecki model społecznej gospodarki rynkowej jako wzór dla polskich przemian systemowych po 1989 roku, Elipsa, Warszawa 2015.

Dandashly A., Verdun A., Euro adoption in the Czech Republic, Hungary and Poland: Laggards by default and laggards by choice, „Comparative European Politics” 2018, Vol. 16(3), https://doi.org/10.1057/cep.2015.46.

Frankel J., Ma X., Xie D., The Impact of Exchange Rate Regimes on Economic Growth with Continuous Classification of de facto Regimes, „Harvard Web Publishing” 2019, https://scholar.harvard.edu/files/frankel/files/fmaxie_errgr_2019apr26.pdf.

Gorzelak G. i in., Co dalej z euro? Trzy scenariusze dla Polski, Polska Fundacja im. Roberta Schumana, Warszawa 2017.

Europejski Bank Centralny, Raport o konwergencji, Frankfurt 2018, https:// doi.10.2866/29295.

29 Zasady takiej polityki omówione są m.in. w: D. Rodrik, Industrial Policy for the Twenty-First Century, CEPR Discussion Paper DP4767, CEPR, London 2004. 
Götz M. i in., Jak żyć z euro? Doświadczenia krajów Europy Środkowo-Wschodniej, Polska Fundacja im. Roberta Schumana, Warszawa 2018.

Götz M., Nowak B.E., Orłowski W.M., Polska w strefie euro? Trzy scenariusze $i$ ich prawdopodobne konsekwencje ogólnoekonomiczne, „Środkowoeuropejskie Studia Polityczne" 2019, nr 1, https://doi.10.14746/ssp.2019.1.7.

Hołda M., Dlaczego Austria (niemal) dogoniła Szwajcarię? [w:] Zagadki wzrostu gospodarczego, red. L. Balcerowicz, A. Rzońca, CH Beck, Warszawa 2010.

Kawalec S., Pytlarczyk E., Paradoks euro. Jak wyjść z pułapki wspólnej waluty?, Poltext, Warszawa 2016.

Narodowy Bank Polski, Raport na temat petnego uczestnictwa Rzeczypospolitej Polskiej w trzecim etapie Unii Gospodarczej $i$ Walutowej, Warszawa 2009.

Obstfeld M., Ostry J.D., Qureshi M.S., Global Financial Cycles and the Exchange Rate Regime: A Perspective from Emerging Markets, „AEA Papers and Proceedings” 2018, Vol. 108.

OECD, The Sources of Economic Growth in OECD Countries, OECD, Paris 2003.

Orłowski W.M., Dlaczego Polska powinna przyjąć euro? [w:] Ekonomia i polityka. Wokót teorii Grzegorza W. Kołodko, red. E. Mączyńska, PWN, Warszawa 2019.

Orłowski W.M., W pogoni za straconym czasem. Wzrost gospodarczy w Europie Srodkowo-Wschodniej 1950-2030, PWE, Warszawa 2010.

Rodrik D., Industrial Policy for the Twenty-First Century, CEPR Discussion Paper DP4767, CEPR, London 2004.

Wong K.-M.,Tai-Leung Chong T., Monetary policy regimes and growth revisited: evidence from a de facto classification, „Oxford Economic Papers” 2019, Vol 71, No 4, https:// doi.10.1093/oep/gpy068. 